\title{
The Relationships of Contextual Performance with Person-Organization Fit, Perceived Organizational Prestige and Organizational Identity Strength: the Mediating Role of Organizational Commitment
}

\author{
Hatem Öcel Collen
}

Abstract

The primary purpose of this paper is to investigate whether affective, normative and continuance commitment mediates the relationships between person-organization fit, perceived organizational prestige, organizational identity strength and contextual performance. Contextual performance does not contribute through the organization's core technical process but it does maintain the broader organizational, social and psychological environment in which the technical core must function (Borman and Motowidlo, 1993). They said that "contextual performance includes activities that promote the viability of the social and organizational network and enhance the psychological climate in which the technical core is embedded; activities such as helping and cooperating with others; following organizational rules and procedures even when personally inconvenient; endorsing, supporting and defending organizational objectives; persisting with extra enthusiasm when neccessary to complete own task successfully; and volunteering to carry out task activities that are not formally part of the job" (Borman and Motowidlo, 1993).Such growth in the number of studies addressing to determining which factors affect the contextual performance. In this studies conscientiousness (Kamdar and Van Dyne, 2007), job satisfaction (Bowling, 2010; Crede, Chernyshenko, Bagraim and Sully, 2009), organizational justice and emotional intelligence (Devonish and Greenidge, 2010), perceived external prestige and affective commitment (Carmeli, 2005) was examined. Carmeli emphasized that employees who hold strong affective commitment are more likely to be involved in organizational citizenship behavior than employees possessing weak affective commitment. Muhammad (2014) also pointed out that when employee received an organizational support from his/her own organization this might be working as an impulsion for his/her organizational behaviors. In addition, it would be reasonable to analysis cause effect of person-organization fit, oragnizational identity strength, and perceived organizational prestige on organizational commitment and contextual performance.

Keywords: relationship, contextual, performance, person-organization, organization, prestige, organizational, identity strength, mediating, role, organizational, commitment

\section{Introduction}

Person-organization fit is defined as compatability between characteristics of the people such as personality, values, goals, and those of the organization such as culture, values goals and norms (Ostrof, Shin and Kinicki, 2005). They maintain that when individuals' values are consistent with the organization's values as defined by the manager, interpersonal interactions, cognitive processing of information, and communication are facilitated, thereby leading to more positive work attitudes. Arthur and colleaqes considered person-organization fit as a criteria of the personel sellection processing. The results indicate that person-organization fit is good predictor of job performance and turnover behavior (Arthur, Bell, Doverspike, Villado, 2006). On the other hand, it could be thought organizational identity strength also has an effect on the contextual performance. Mainly organizational identity strength taken in hand as the extent to which individual member's identity perceptions are widely held and deeply shared (Kreiner and Ashforth, 2004). Organization members use an organization's image which is the way they believe others see the organization, to deliberate how outsiders are judging them. The organizational identity strength construct is theoretically distinguishable from the concept of organizational identity because, whereas an organization's identity captures the essential features believed to be central, enduring, and distinctive of an organization (Albert and Whetten, 1985), organizational identity strength reflects the degree to which its members perceive the identity as being special or unique (Milliken, 1990). Each member's own construal of the organization's external image may or may not match the reputation of the organization in the minds of outsiders (Dutton, Dukerich and Harquail, 1994). There have been no studies of a direct relationship between organizational identity strength and contextual performance. 
According to Ostrof and colleages when the employee have strength organizational identity they will display positive work behaviors (Ostrof, Shin and Kinicki, 2005). From this point, the study includes organizational identity strength as well. The last variable that examine effect on the contextual performance is perceived organizational prestige. Organizational prestige is the feelings of members about outsiders' perceptions of the organization. Members' identification is sensitive to how they think outsiders view the organization. While the perceived organizational identity is a member's assessment of the organization's character, construed external image refers to a member's beliefs about outsiders' perceptions of the organization. The construed external image provides more than just information about the probable social evaluation of the organization. Carmeli (2005) indicated that perceived external prestige and citizenship behaviors will be mediated by affective commitment. Perceived external prestige seems to have a larger effect on employee affective commitment.

Organizational commitment is affective attachment to the organization, perceived costs associated with leaving the organization, and obligation to remain with the organization (Meyer and Allen 1991). In short organizational commitment to be composed of three parts. These are affective commitment, normative commitment and continuence commitments. According to Meyer and Allen (1991), affective commitment indicates that an employee is committed to the organization for emotional reasons. The people working in the workplace have a strong affective commitment continue to stay in an organization because they want to do so. Continuence commitment refers to an awareness of the costs associated with leaving from the organization. Workers have a high level of continuence commitment remain because they need to do so. Finally, normative commitment reflects a feeling of obligation to continue to work. The mployees feel high level of normative commitment they ought to remain with the organization (Meyer and Allen, 1991). When the employees feel organizational commitment to the organization they will display voluntarly more positive social behavior for the organization and they want to be continue to work for the organization. In another words they will be willing to show extra role behaviors on the positive side or the negative one. In fact recent meta-analytic evidence has reported commitment to predict a wide range of job attitudes such as turnover intention, citizenship behaviors etc. (Cooper-Hakim and Viswesvaran, 2005; Meyer et al., 2002).

From this perspective, the aim of the present study was to determine the mediator role of organizational commitment in the relationship between person-organization fit, perceived organizational prestige, organizational identity strength and contextual performance. Accordingly, the following hypothesis is suggested:

Hypothesis 1: The relationship between person-organization fit, perceived organizational prestige, organizational identity strength and contextual performance will be mediated by the affective commitment.

Hypothesis 2: The relationship between person-organization fit, perceived organizational prestige, organizational identity strength and contextual performance will be mediated by the normative commitment.

Hypothesis 3: The relationship between person-organization fit, perceived organizational prestige, organizational identity strength and contextual performance will be mediated by the continuance commitment.

\section{Method}

\section{Participants}

A total of 190 questionnaires were distributed to academic staff at Karabük University. The participants aged between 22 and 56 years old $(\bar{X}=33.15$, ss $=7.71)$ and the tenure of the participants changed between 1 and 20 years $(\bar{X}=3.20$, ss= 3.95). Respondents were 57 female (\% 30) and 132 male ((\% 69.5) and the rest of them did not mentioned about the marital status.

\section{Materials}

Demografic Information Form. In this study demographic information form was used for collecting data about participants' age, sex, marital status, academic position in a üniversity (professor, lecturer, assistant professor etc.) and tenure.

Contextual Performance Scale. This 5-point Likert type scale developed by Borman and Motowidlo (1993). It was translated in Turkish by Karakurum (2005) using 5 items of 11. 5-point scale rangign from never to always. The internal reliability alpha score was found .80 for Turkish sample (Karakurum, 2005).

Organizational Commitment Scale. The scale, 7-point Likert type was developed by Allen and Meyer (1990) consisting 24 items. The scale has three subscales identified as affective commitment, normative commitment and continuence 
commitment. In the present study, the Cronbach Alpha scores for affective commitment, normative commitment and continuence commitment were .84, .82 and .70, respectively (Wasti, 2003).

Person-Organization Fit Scale. To determine how similar values there are between employees and their organizations and colleaques the person-organization fit scale was used (Cable and Judge, 1996). This 5-point Likert type scale was adapted to Turkish by Karakurum (2005) have 3 items ("My values match those of current employees in organization") and ranging from $1=$ not at all to $5=$ completely. The resulting internal consistency estimate for the three-item scale was .84 (Karakurum, 2005).

Perceived Organizational Prestige. This scale was developed to measure of the perceived organizational prestige (Mael and Ashforth, 1992). Perceived Organizational Prestige Scale consists of 8 items (This organization does not have a good reputation in my community). Each item is rated between 1 to 5 ( $1=$ Strongly agree; $5=$ Strongly disagree). The scale was adapted in Turkish by Güleryüz (2010) and coefficant alpha was found .77.

Organization Identity Strength. Organizational identity strength was measured with Kreiner and Ashforth's (2004) fouritem scale ("This organization has a clear and unique vision"). Each item is rated between 1 to $5(1=$ Strongly disagree; $5=$ Strongly agree). The scale was adapted in Turkish by Güleryüz (2010) and internal consistency of the scale was .86 .

\section{Procedure}

All questionnaires were administered to the participants in their rooms.

Table 1. Correlations, means and standart deviations

\begin{tabular}{|c|c|c|c|c|c|c|c|c|c|c|}
\hline & 1 & 2 & 3 & 4 & 5 & 6 & 7 & 8 & 9 & 10 \\
\hline \multicolumn{11}{|l|}{ 1.Age } \\
\hline 2.Gender & $.25^{\star \star}$ & & & & & & & & & \\
\hline 3.Tenure & $.44^{\star *}$ & $.17^{\star}$ & & & & & & & & \\
\hline 4.Person-Organiztion Fit & $.20^{* *}$ & $.24^{\star *}$ & .13 & $(.84)$ & & & & & & \\
\hline 5.Örganizational Prestige & $.27^{* *}$ & .09 & .07 & $.60^{\star *}$ & $(.77)$ & & & & & \\
\hline 6.Örgan. Identity Strength & $.20^{* *}$ & .04 & .08 & $.52^{\star *}$ & $.58^{\star \star}$ & $(.86)$ & & & & \\
\hline 7.Contextual Performance & $.19^{* *}$ & .12 & .06 & $.47^{* *}$ & $.52^{\star *}$ & $.49^{* *}$ & $(.80)$ & & & \\
\hline 8.Affective Commitment & $.35^{\star *}$ & $.25^{\star \star}$ & $.22^{\star *}$ & $.64^{* *}$ & $.65^{\star *}$ & $.58^{\star *}$ & $.60^{* *}$ & $(.84)$ & & \\
\hline 9.Normative Commitment & $.28^{\star *}$ & $.24^{\star *}$ & $.14^{*}$ & $.59^{\star *}$ & $.50^{* *}$ & $.51^{\star *}$ & $.48^{* *}$ & $.73^{* *}$ & $(.82)$ & \\
\hline 10.Continuance Commitment & .07 & $.19^{* *}$ & $.19^{* *}$ & $.30^{\star *}$ & $.31^{* *}$ & $.28^{\star *}$ & $.19^{* \star}$ & $.42^{* *}$ & $.54^{* *}$ & $(.70)$ \\
\hline Means & 33.15 & - & 3.20 & 9.93 & 29.26 & 14.69 & 19.15 & 65.64 & 43.68 & 36.17 \\
\hline Stand. Deviat. & 7.71 & - & 3.95 & 2.80 & 5.88 & 3.18 & 3.76 & 15.89 & 12.66 & 9.21 \\
\hline Female 1(Mean) & 30.16 & - & 2.19 & 8.91 & 28.40 & 14.43 & 18.43 & 59.47 & 38.96 & 33.38 \\
\hline Male 2 (Mean) & 34.46 & - & 3.65 & 10.39 & 29.65 & 14.76 & 19.41 & 68.28 & 45.65 & 37.28 \\
\hline
\end{tabular}

\section{Results}

In this study, regression analyses were done to the test the relationships between contextual performance and personorganization fit, perceived organizational prestige, organizational identity strength. It has been performed a series of hierarchical regression analyses while controlling for the effects of age, gender, and tenure in a first step. Results showed that affective commitment and normative commitment have a mediating role in between the person-organization fit, 
perceived organizational prestige, organizational identity strength and contextual performance. Provided that continuance commitment does not any mediator role in these relationships.

Table 2. Regressions Analyses for Affective, Normative and Continuance Commitment

\begin{tabular}{|c|c|c|c|c|c|c|c|}
\hline \multicolumn{8}{|c|}{ Dependent Variable: Organizational Commitment } \\
\hline \multicolumn{8}{|l|}{ Affective Commitment } \\
\hline \multirow[t]{2}{*}{ Variables } & $B$ & $\beta$ & $t$ & $p$ & $R^{2}$ & Adjusted & $F$ \\
\hline & & & & & & $R^{2}$ & \\
\hline Age & .57 & .28 & $3.57^{* *}$ & .00 & & & \\
\hline Gender & 6.38 & .18 & $2.60^{* *}$ & .01 & .16 & .15 & $11.59^{\star *}$ \\
\hline Tenure & .26 & .06 & .84 & .39 & & & \\
\hline Person-Organization Fit & 3.29 & .57 & $10.0^{* *}$ & .00 & & & \\
\hline Örganizational Prestige & 1.19 & .42 & $6.77^{* *}$ & .00 & .60 & .59 & $44.84^{* *}$ \\
\hline Örgan. Identity Strength & 1.12 & .21 & $3.58^{\star *}$ & .00 & & & \\
\hline \multicolumn{8}{|l|}{ Normative Commitment } \\
\hline Age & .37 & .23 & $2.91^{* *}$ & .00 & & & \\
\hline Gender & 5.41 & .20 & $2.76^{* *}$ & .00 & .12 & .10 & $8.14^{* *}$ \\
\hline Tenure & .01 & .00 & .01 & .94 & & & \\
\hline Person-Organiztion Fit & 2.47 & .55 & $9.10^{* *}$ & .00 & & & \\
\hline Organizational Prestige & .52 & .24 & $3.30^{* *}$ & .00 & .46 & .44 & $25.17^{* *}$ \\
\hline Örgan. Identity Strength & .84 & .20 & $2.95^{\star *}$ & .00 & & & \\
\hline \multicolumn{8}{|l|}{ Continuance Commitment } \\
\hline Age & -.06 & -.05 & -.66 & .51 & & & \\
\hline Gender & 3.29 & .16 & $2.22^{*}$ & .02 & .06 & .04 & $4.02^{\star *}$ \\
\hline Tenure & .43 & .19 & $2.35^{\star}$ & .02 & & & \\
\hline Person-Organiztion Fit & .94 & .29 & $3.97^{* *}$ & .00 & & & \\
\hline Organizational Prestige & .38 & .24 & $2.75^{\star *}$ & .00 & & & \\
\hline Örgan. Identity Strength & .31 & .10 & 1.22 & .22 & .18 & .15 & $6.56^{\star *}$ \\
\hline
\end{tabular}

Table 3. Regression Results Involving Affective Commitment as a Mediator

\begin{tabular}{llllll}
\hline Variables & $\beta$ & $\mathrm{t}$ & $R^{2}$ & $R^{2}$ chang. & $\mathrm{F}$
\end{tabular}




\begin{tabular}{llllll}
\hline Step 1 & & & .04 & .04 & $2.93^{*}$ \\
Age & .09 & $2.27^{*}$ & & & \\
Gender & .69 & 1.14 & & & \\
Tenure & -.02 & -.36 & & & \\
Step 2 & & & .36 & .32 & $16.57^{* *}$ \\
Age & .01 & .51 & & & \\
Gender & .22 & .43 & & & \\
Tenure & -.01 & -.24 & & & \\
Person-Organiztion Fit & .23 & $2.18^{*}$ & & & \\
Organizational Prestige & .19 & $3.70^{* *}$ & & & \\
Organ. Identity Strength & .24 & $2.66^{* *}$ & & & \\
Step 3 & & & .42 & .06 & $17.98^{* *}$ \\
Age & -.00 & -.03 & & & \\
Gender & -.10 & -20 & & \\
Tenure & -.04 & -.71 & & \\
Person-Organiztion Fit & .10 & .98 & & \\
Organizational Prestige & .11 & $2.04^{*}$ & & \\
Organ. Identity Strength & .14 & $1.60^{*}$ & & \\
Affective Commitment & .08 & $4.14^{* *}$ & & \\
\hline
\end{tabular}

${ }^{*} p<.05,{ }^{* *} p<.01$

Table 4. Regression Results Involving Normative Commitment as a Mediator

\begin{tabular}{lllllll}
\hline Variables & $\beta$ & $\mathrm{t}$ & $R^{2}$ & $R^{2}$ chang. & $\mathrm{F}$ \\
& & & & & \\
\hline Step 1 & & & .04 & .04 & $2.93^{*}$ \\
Age & .09 & $2.27^{*}$ & & & \\
Gender & .69 & 1.14 & & & \\
Tenure & -.02 & -.36 & & & \\
Step 2 & & & .36 & .32 & $16.57^{* *}$ \\
Age & & & & & \\
Gender & .01 & .51 & & & \\
Tenure & .22 & .43 & & & \\
Person-Organiztion Fit & -.01 & -.24 & & & \\
Organizational Prestige & .23 & $2.18^{*}$ & & & \\
& & .19 & $3.70^{* *}$ & & & \\
\hline
\end{tabular}


Step 3

$.38 .02 \quad 15.49^{* *}$

Age $.00 \quad .24$

Gender $.04 \quad .08$

Tenure $-.01 \quad-.26$

Person-Organiztion Fit $.14 \quad 1.27$

Organizational Prestige $.173 .31^{* *}$

Organ. Identity Strength $.192 .10^{*}$

Normative Commitment

$.062 .46^{*}$

${ }^{*} p<.05,{ }^{* *} p<.01$

Table 5. Regression Results Involving Continuance Commitment as a Mediator

\begin{tabular}{|c|c|c|c|c|c|}
\hline Variables & $\beta$ & $t$ & $R^{2}$ & $R^{2}$ chang. & $\mathrm{F}$ \\
\hline Step 1 & & & .04 & .04 & $2.93^{*}$ \\
\hline Age & .09 & $2.27^{*}$ & & & \\
\hline Gender & .69 & 1.14 & & & \\
\hline Tenure & -.02 & -.36 & & & \\
\hline Step 2 & & & .36 & .32 & $16.57^{\star \star}$ \\
\hline Age & .01 & .51 & & & \\
\hline Gender & .22 & .43 & & & \\
\hline Tenure & -.01 & -.24 & & & \\
\hline Person-Organiztion Fit & .23 & $2.18^{*}$ & & & \\
\hline Organizational Prestige & .19 & $3.70^{\star *}$ & & & \\
\hline Organ. Identity Strength & .24 & $2.66^{\star \star}$ & & & \\
\hline \multicolumn{6}{|l|}{ Step 3} \\
\hline Age & -- & -- & -- & -- & -- \\
\hline \multicolumn{6}{|l|}{ Gender } \\
\hline \multicolumn{6}{|l|}{ Tenure } \\
\hline \multicolumn{6}{|l|}{ Person-Organiztion Fit } \\
\hline \multicolumn{6}{|l|}{ Organizational Prestige } \\
\hline $\begin{array}{l}\text { Organ. Identity Strength Continuance } \\
\text { Commitment }\end{array}$ & & & & & \\
\hline
\end{tabular}


${ }^{*} p<.05,{ }^{* *} p<.01$

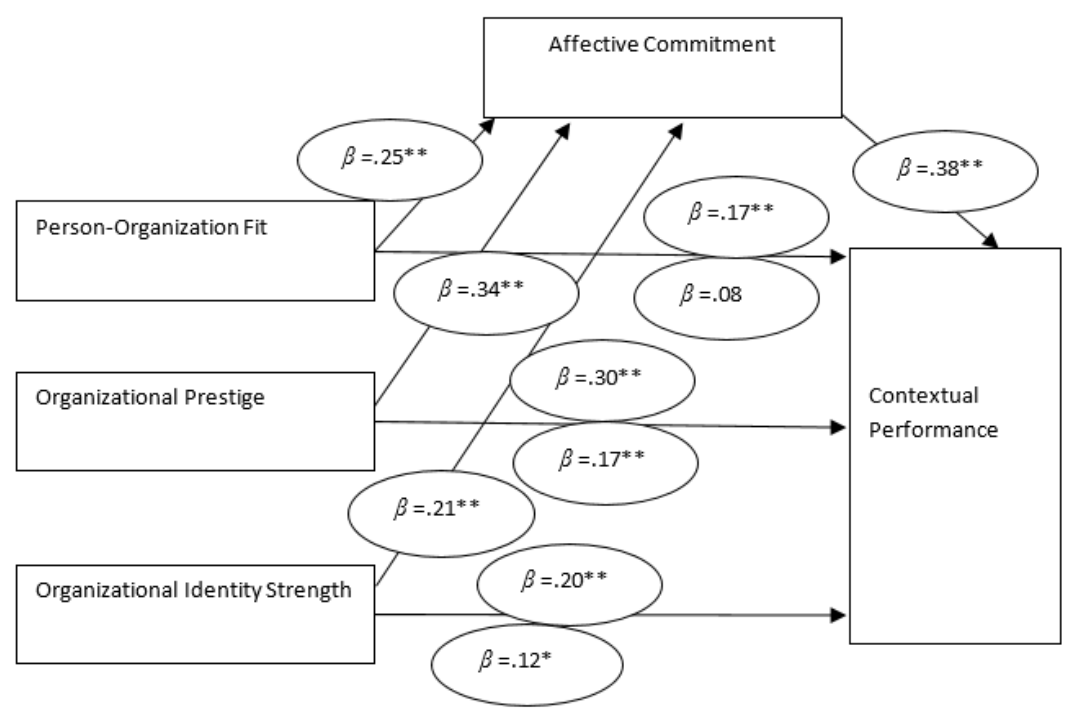

Figure 1. Mediating effects of affective commitment on the relationship between person-organiztion fit, organizational prestige, organizational identity strength and contextual performance. ${ }^{*} p<.05,{ }^{* *} p<.01$

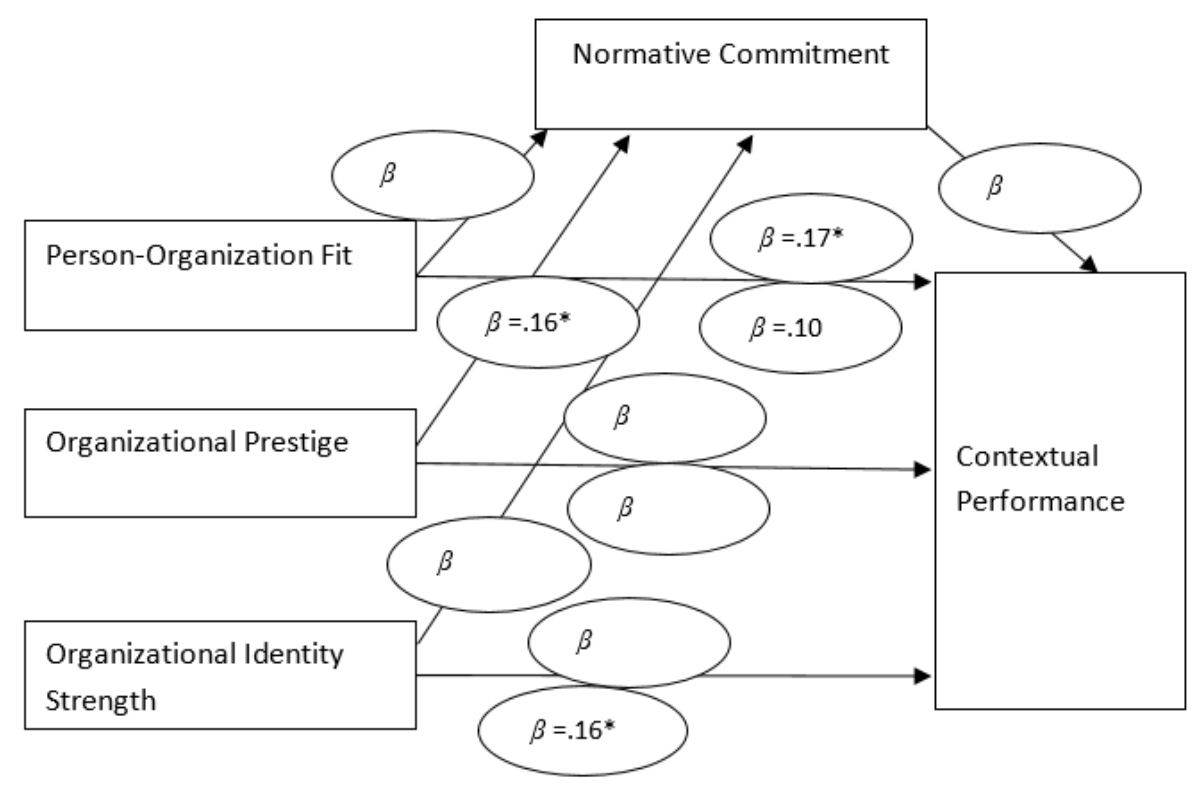




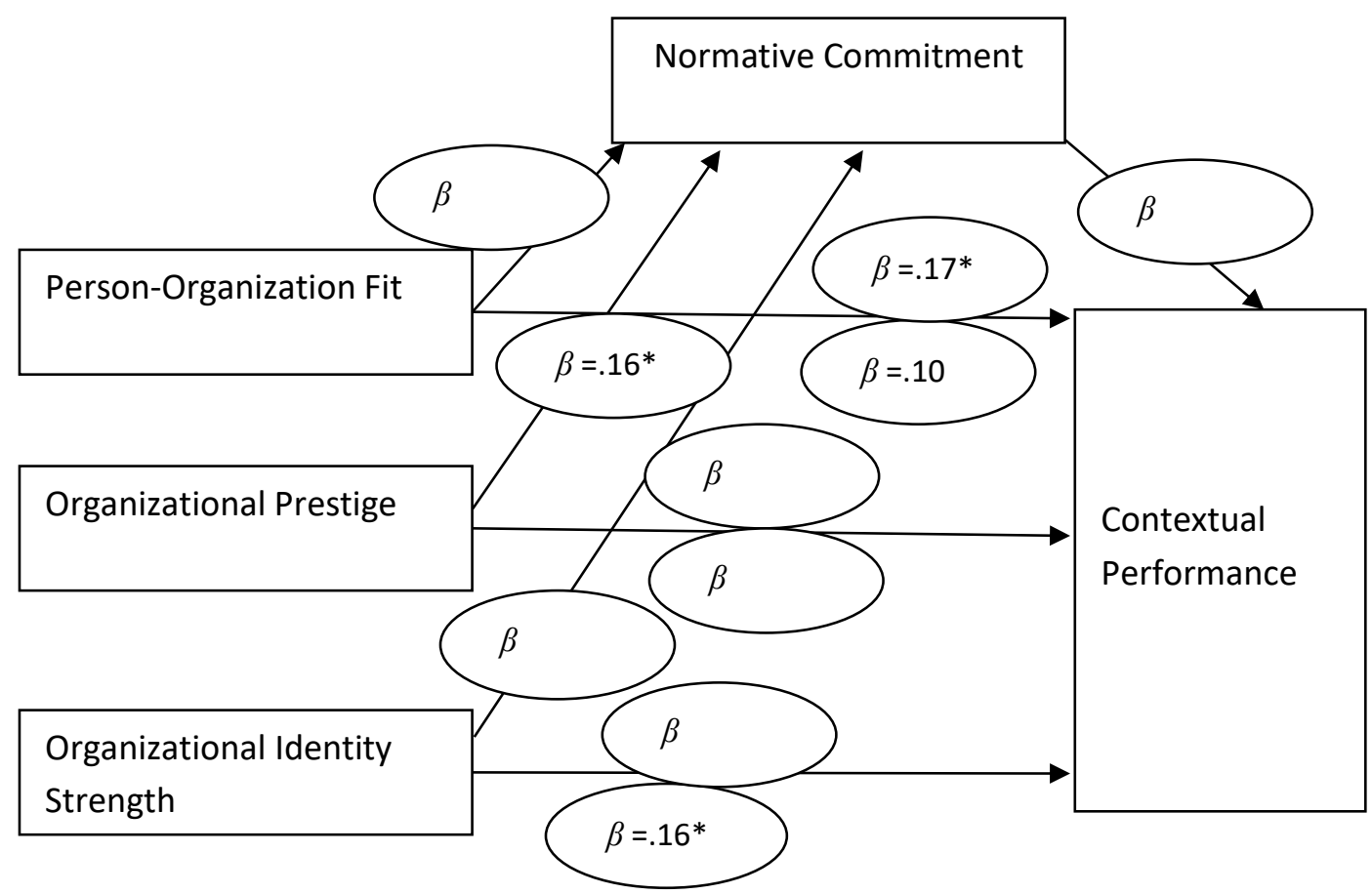

Figure 2. Mediating effects of normative commitment on the relationship between person-organiztion fit, organizational prestige, organizational identity strength and contextual performance. ${ }^{*} p<.05,{ }^{* *} p<.01$

\section{Discussion and Limitations}

In the present study it has been studied the mediator role of organizational commitment in the relationship between personorganization fit, perceived organizational prestige, organizational identity strength and contextual performance.

The results of the study showed that perceived organizational prestige predict contextual performance. According to Dutton and Dukerich organizational image fosters the identification of an employee with his/her organization (Dutton and Dukerich 1991; Dutton et al. 1994). An employee is likely to develop a strong attachment to an organization that holds favorable prestige (reputation) as part of his/her connection with reflected glory which, in turn, translates into citizenship behaviors (Dutton et al. 1994). Similarly, Saboor, Rehman, and Rehman (2018) have shown in their study, organizational respect improve the contextual performance in the organization. Moreover, positive perception of organizational image by workers lead to improve their performance (Dhir \& Shukla, 2019).

In previous reviews of the literature, it has been suggested that $\mathrm{PO}$ fit would be more strongly related to organizationallevel outcomes like OCB (Hofmann ve Woehr, 2006). As expected, it is found that organizational identity strength also predict contextual performance. While strong organizational identity has a positive relationship between organizational citizenship behaviors and performance negative relationship between turnover (Abrams, Ando and Hinkle, 1998; Mael and Ashforth, 1995). Finally person-organization fit, also predict contextual performance. According to main aim the study, the regression analysis results have revelead that the affective and normative commitment have mediator role in between person-organization fit, perceived organizational prestige, organizational identity strength and contextual performance. However, continuance commitment does not have any mediator role in this relationships. Converserly, third hypotheses has not been supported. This study has a number of limitations that should be acknowledged: First, there is a possible risk of common method bias in this study due to the use of self-report instrument to collect data from a single source. Although constructs such as P-O fit, organizational commitment, and OCB are typically measured using self-report data, I cannot 
rule out the possibility of common method bias. However, future research could lessen this risk by asking questions at different points in time or designing separate questionnaires for collecting data from multiple respondents. Second, the results of the study are, therefore, specific to this group, and extrapolation of the results to other settings and environments may not be suitable without further evaluations of those situations.

\section{References}

[1] Abrams, D., Ando, K., ve Hinkle, S. (1998). Psychological attachment to the group: Cross-cultural differences in organizational identification and subjective norms as predictors of workers' turnover intentions. Personality and Social Psychology Bulletin, Vol. 24, Iss. 10, s.1027-1040.

[2] Albert, S., \& Whetten, D. A. (1985). Organizational identity. Research in Organizational Behavior, 7, 263-295.

[3] Allen, N. J. ve Meyer, P. (1990), The measurement ve antecedents of affective, continuance ve normative commitment to the organization. Journal of Occupational Psychology, Vol.63, s.1-18.

[4] Arthur, W. Jr., Bell, S. T., Doverspike, D. ve Villado, A. J. (2006). The use of person-organization fit in employment decision making: An assessment of its criterion-related validity. Journal of Applied Psychology,Vol.91, No:4, s.786-801.

[5] Bowling, N. A. (2010). Effects of job satisfaction and conscientiousness on extra-role behaviors. Journal of Bussiness Psychology, Vol.25, s. 119-130.

[6] Borman, W. C. ve Motowidlo, S. J. (1993). Expanding the criterion domain to include elements of contextual performance. In Neil Schmit and Walter C. Borman (Eds) Personal selection in organizations, San Fransisco: Jossey-Bass.

[7] Cable, D. ve Judge, T. A. (1996). Interviewers' perceptions of person-organization fit and organizational selection decisions. Journal of Applied Psychology, Vol.82, No:4, s.546-561.

[8] Carmeli, A. (2005). Perceived external prestige, affective commitment, and citizenship behaviors. Organization Studies, Vol.26, No:3, s.443-464.

[9] Cooper-Hakim, A., and Viswesvaran, C. (2005). The construct of work commitment: testing an integrative framework. Psychological Bulletin, 131, 241-259.

[10] Crede, M., Chernyshenko, O. S., Bagraim, J. ve Sully, M. (2009). Contextual performance and the job satisfaction-dissatisfaction distinction: Examining artifacts and utility. Human Performance, Vol. 22, s.246-272.

[11] Devonish, D. ve Greenidge, D. (2010). The effect of organizational justice on contextual performance, counterproductive work behaviors, and task performance: Investigating the moderating role of ability-based emotional intelligence. International Journal of Selection and Assessment, Vol.18, No:1, s.75-86.

[12] Dhir, S., \& Shukla, A. (2019). Role of organizational image in employee engagement and performance. Benchmarking: An International Journal.

[13] Dutton, J. E. ve Dukerich, J. M. (1991). Keeping an eye on the mirror: Image and identity in organizational adaptation. Academy of Management Journal, Vol.34, No:3, s.517-554.

[14] Dutton, J. E., Dukerich, J. M., ve Harquail, C.V. (1994). Organizational images ve member identification. Administrative Science Quarterly, Vol.39, s.239-263.

[15] Güleryüz, E. (2010). Öncülleri ve Sonuçalrı Bağlamında Örgütsel Özdeşimin Örgütsel Bağlılığın Duygusal Bağılık Boyutuyla Illişkisi. Yayınlanmamış doktora tezi, Hacettepe Üniversitesi, Ankara.

[16] Hoffman, B. J. ve Woehr, D. J. (2006). A quantitative review of the relationship between person-organization fit and behavioral outcomes. Journal of Vocational Behavior, Vol.68, s.389-399.

[17] Kamdar, D., ve Van Dyne, L. (2007). The joints effects of personality and workplace social exchange relationships in predicting task performance and citizenship performance. Journal of Applied Psychology, Vol.92, No:5, s. $1286-1298$.

[18] Karakurum, M. (2005). The effects of person-organization fit employee job satisfaction, performance ve organizational commitment in a Turkish public organization. Unpublished master's thesis, Middle East Technical University, Ankara.

[19] Kreiner, G. E., ve Ashforth, B. E. (2004). Evidence toward an expanded model of organizational identification. Journal of Organizational Behavior, Vol.25, s.1-27.

[20] Kristof-Brown, A. L. (1996). Person-organization fit: An integrative review of its conceptualizations, measurement and implications. Personnel Psychology, Vol. 49, No:1, s.1-49. 
[21] Mael, F., ve Ashforth, B. E. (1992). Alumni and their alma mater: A partial test of the reformulated model of organizational identification. Journal of Organizational Behavior, Vol.13, s.103-123.

[22] Mael, F., ve Ashforth, B. E. (1995). Loyal from day one: Biodata, organizational idendification, and turnover among newcomers. Personnel Psychology, Vol.48, s.309-333.

[23] Meyer, J. P., ve Allen, N. J. (1991). A three-component conceptualization of organizational commitment. Human Resources Management Review, Vol.1, No:1, s.61-89.

[24] Meyer, J. P., Stanley, D. J., Herscovitch, L., and Topolnytsky, L. (2002). Affective, continuance, and normative commitment to the organization: a meta-analysis of antecedents, correlates, and consequences. Journal of Vocational Behavior, 61, 20-52.

[25] Milliken, F. J. (1990). Perceiving and interpreting environmental change: an examination of college administrators' interpretation of changing demographics. Academy of Management Journal, 33, 42-63.

[26] Muhammad, A.H. (2014). Perceived organizational support and organizational citizenship behavior: The case of Kuwait. International Journal of Business Administration, 5, 59-72.

[27] Ostroff, C., Shin, Y.Y., ve Kinicki, A. J. (2005). Multiple perspectives of congruence: relationship between value congruence and employee attitudes. Journal of Organizational Behavior, Vol.26, s. 591-623.

[28] Saboor, A., Rehman, M., \& Rehman, S. (2018). Organizational justice and employee contextual performance: the moderating effect of organizational respect. Pakistan Business Review, 19(4), 995-1011.

[29] Wasti, S. A. (2003). Organizational commitment, turnover intentions and the influence of cultural values. Journal of Occupational and Organizational Psychology, Vol.76, s.303-321. 